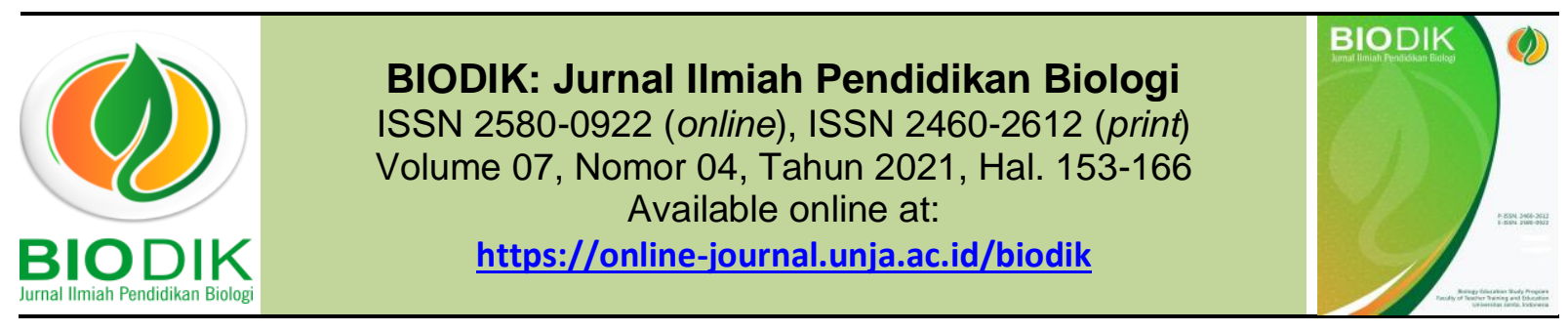

Research Article

open ACCESS

\title{
Analisis Implementasi Model Pembelajaran Berbasis Daring pada Mata Pelajaran Biologi Kelas XI
}

\author{
(Implementation Analysis of online-Based Learning Model in Class XI Biology)
}

\author{
A. Farid Rohmatulloh*, Nur Khoiri, Ndzani Latifatur Rofi'ah \\ Pendidikan Biologi, UIN Walisongo Semarang \\ Jl. Prof. Hamka (Kampus III) N galiyan Semarang 50185 \\ *Corresponding Authors : faridrohmatulloh1@gmail.com
}

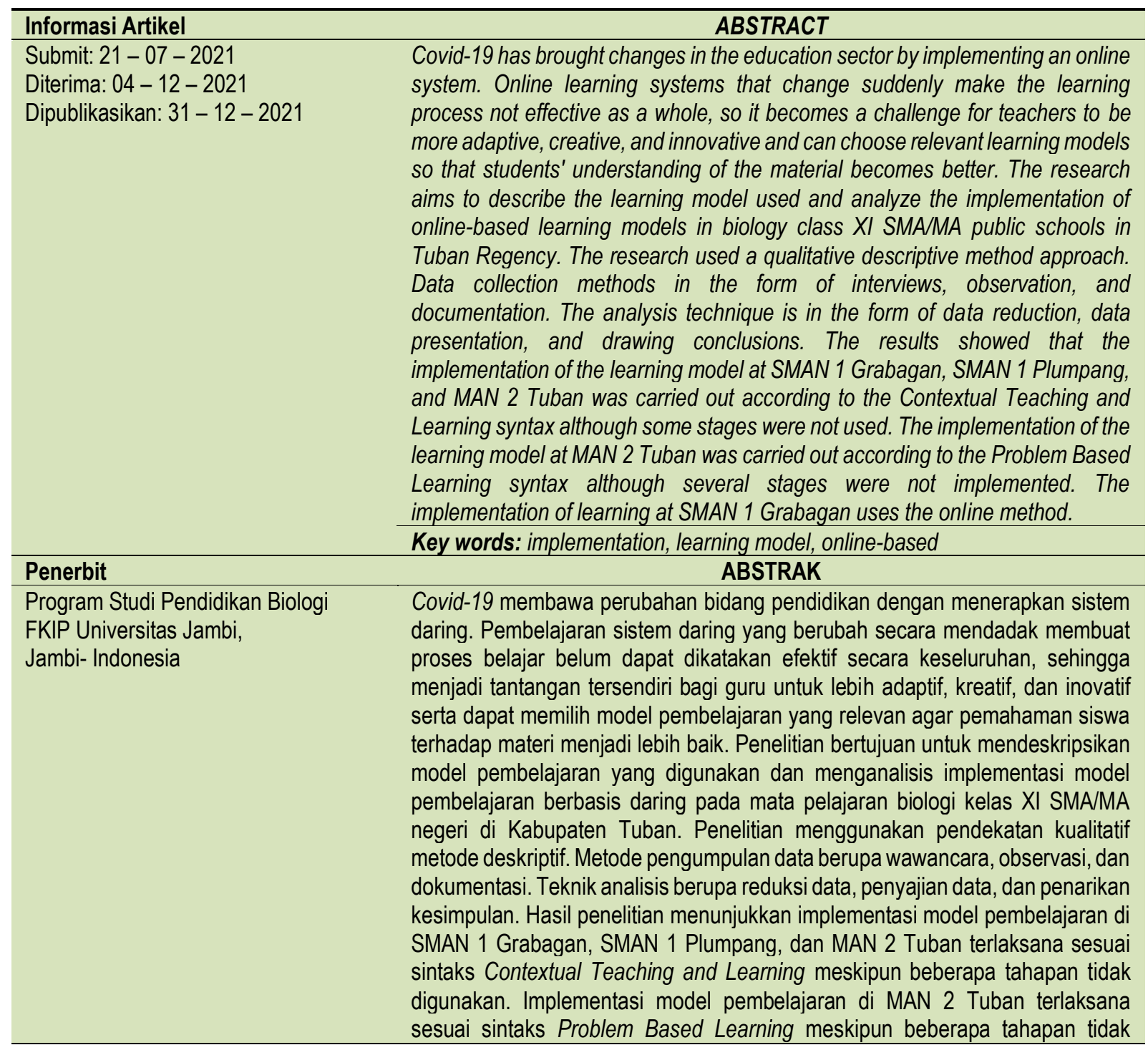




\section{PENDAHULUAN}

Wabah Coronavirus jenis baru yang muncul dari Wuhan Provinsi Hubei, China pada akhir tahun 2019 mengejutkan dunia (Hui dkk., 2020). Covid-19 (Corona Virus Disease-19) membawa perubahan dalam berbagai aspek kehidupan, salah satu dampaknya juga dirasakan dalam bidang pendidikan (Herliandry, 2020). Aktivitas yang melibatkan kumpulan orang-orang kini mulai dibatasi seperti sekolah, bekerja, beribadah di rumah untuk mengurangi penyebaran kasus Covid-19. Kebijakan yang diambil oleh pemerintah Indonesia adalah dengan melaksanakan aktivitas pendidikan secara daring (dalam jaringan). Dalam hal ini pemerintah membuat kebijakan alternatif terkait proses pembelajaran untuk peserta didik. Menteri Nadiem Anwar Makarim menerbitkan surat Edaran Nomor 3 Tahun 2020 pada Satuan Pendidikan dan Nomor 36962/MPK.A/HK/2020 tentang Pelaksanaan Pendidikan dalam Masa Darurat Corona Virus Disease-19 (Covid-19) maka kegiatan belajar dilakukan secara daring (online) dalam rangka pencegahan penyebaran Corona Virus Disease-19 (Covid-19) (Menteri Pendidikan, 2020). Pelaksanaan pembelajaran dengan sistem daring yang berubah secara mendadak membuat proses belajar dari rumah belum dapat dikatakan efektif secara keseluruhan karena terdapat banyak kendala.

Kendala pelaksanaan pembelajaran daring antara lain adalah masalah akses sinyal internet (Sukanto, 2020; Kementerian Pendidikan dan Kebudayaan, 2020; Lestariyanti, 2020). Tahun 2020 terdapat 8.281 atau $3 \%$ dari satuan pendidikan yang belum terpasang listrik dan 46.272 atau $18 \%$ dari satuan pendidikan dasar dan menengah yang tidak terdapat akses internet. Selain itu, siswa yang berada di daerah perdesaan terpencil dan tertinggal juga menghadapi kendala jaringan dalam mengakses internet. Hal ini berkaitan erat dengan letak geografis Indonesia yang memberi pengaruh pada keterjangkauan sinyal atau jaringan provider. Indonesia memiliki total pulau sebanyak 17.000 dengan panjang dari barat hingga timur mencapai 5.106 km, sehingga kualitas koneksi internet tidak stabil dan merata di berbagai daerah. Kendala lain dalam pembelajaran diungkapkan oleh Firman \& Rahayu (2020) yaitu beban biaya yang digunakan untuk pembelian kuota internet. Jika dihitung, rata-rata biaya kuota internet yang harus dikeluarkan oleh siswa yaitu antara Rp80.000 hingga Rp200.000 per minggu bergantung provider seluler yang digunakan.

Muthuprasad dkk. (2020) melaporkan bahwa kendala teknologi, gangguan sinyal, ketidakmampuan guru, ketidakefektifan siswa, dan masalah kesehatan adalah tantangan dalam belajar online. Pembelajaran dapat menjadi efektif dan produktif dengan mempertimbangkan preferensi dan persepsi siswa saat merancang pembelajaran online. Preferensi siswa erat kaitannya dengan kesiapan atau kemauan siswa untuk berpartisipasi dalam pembelajaran. Beberapa studi menunjukkan bahwa interaksi antara guru dengan siswa memiliki pengaruh yang besar pada persepsi siswa tentang pembelajaran online. Sejumlah $60 \%$ responden setuju bahwa kelas online kurang efektif dalam hal komunikasi dengan guru dibandingkan dengan kelas tatap muka.

Adanya pembelajaran daring juga menjadi tantangan baru bagi para guru. Guru harus bisa menguasai media pembelajaran daring dan berkreasi dalam proses pembelajaran supaya tujuan 
pembelajaran dapat tercapai (Mantra, 2020). Hal ini senada dengan penelitian yang dilakukan oleh Lestariyanti (2020) bahwasanya tantangan pembelajaran daring adalah kreativitas pendidik. Menurut Verawardina dkk. (2020) dalam penerapan pembelajaran daring, pendidik atau pengajar diharuskan mampu mendesain dan menggunakan model, metode, dan teknik yang variatif. Hal ini senada dengan yang disampaikan Andersen (2004) bahwa tantangan penerapan pembelajaran daring adalah menentukan model, metode, kegiatan, dan subjek atau aktor yang paling efektif dalam menciptakan dan mendistribusikan program pembelajaran daring agar berkualitas. Anhusadar (2020) menambahkan bahwa kreativitas pengajar dalam pembelajaran daring sangat diperlukan karena memberi pengaruh terhadap peningkatan kreativitas peserta didik. Pendidik juga dituntut memiliki kemampuan mengoperasikan teknologi supaya mampu menyesuaikan konten pelajaran, tuntutan capaian kompetensi, karakteristik peserta didik dengan penggunaan platform pembelajaran daring.

Berdasarkan hasil observasi di MAN 2 Tuban dan SMAN 1 Plumpang diperoleh informasi bahwa kegiatan pembelajaran dilaksanakan secara daring. Hal ini peneliti dapatkan dari hasil wawancara tidak terstruktur dengan salah satu guru di sekolah tersebut yaitu Bapak Lukito, S.Si dan Ibu Piyati, S.Pd. Bapak Lukito mengakui bahwa proses pembelajaran daring dipengaruhi oleh faktor utama yaitu kekuatan jaringan internet serta faktor pendukungnya yang berupa alat komunikasi seperti handphone yang memiliki fitur canggih dan laptop. Hal ini senada dengan yang disampaikan lbu Piyati bahwasannya sinyal internet menjadi kendala utama dalam proses pembelajaran daring. Kualitas sinyal internet yang lemah mengakibatkan proses pembelajaran daring ini tidak berjalan secara maksimal, akibatnya beberapa siswa mengalami kesulitan dalam memahami materi yang disampaikan. Selain siswa, proses pembelajaran daring juga membuat sebagian guru kesulitan dalam mengukur pencapaian siswa dalam memahami materi yang diberikan. Berdasarkan uraian tersebut, penelitian dengan judul Analisis Implementasi Model Pembelajaran Berbasis Daring pada Mata Pelajaran Biologi Kelas XI SMA/MA negeri di Kabupaten Tuban perlu dilakukan.

\section{METODE PENELITIAN}

Jenis penelitian ini adalah kualitatif dengan pendekatan deskriptif. Penelitian ini dilaksanakan di SMA dan MA negeri yang ada di Kabupaten Tuban pada bulan April 2021. Adapun SMA dan MA Negeri yang akan dijadikan lokasi penelitian yaitu SMAN 1 Grabagan, SMAN 1 Plumpang, SMAN 1 Soko, MAN 1 Tuban, dan MAN 2 Tuban. Sumber data dalam penelitian ini adalah guru mata pelajaran biologi kelas XI SMA dan MA negeri di Kabupaten Tuban dan beberapa siswa yang diampu oleh guru biologi kelas XI.

Teknik pengumpulan data dilakukan peneliti melalui wawancara, observasi, dan dokumentasi. Wawancara dilakukan kepada guru pengampu mata pelajaran biologi dan beberapa siswa tentang halhal yang berkaitan dengan implementasi model pembelajaran berbasis daring. Observasi dalam penelitian ini dilakukan dengan pengamatan secara langsung kepada guru berdasarkan lembar observasi yang telah disiapkan. Dokumentasi dilakukan dengan memeriksa RPP yang disusun oleh guru biologi kelas XI saat pembelajaran daring. Analisis data penelitian dilakukan dengan menggunakan model Miles and Huberman yang terdiri atas tiga tahapan, yaitu reduksi data, penyajian data, dan penarikan kesimpulan (Sugiyono, 2016:338).

\section{HASIL PENELITIAN DAN PEMBAHASAN}

Implementasi model pembelajaran berbasis daring pada mata pelajaran biologi di SMAN 1 Grabagan dilakukan dengan menggunakan model pembelajaran Contextual Teaching and Learning 
(CTL). Model pembelajaran CTL menuntuk siswa belajar dengan mendapatkan pengetahuan dari lingkungan yang ada di sekitarnya. Adapun implementasi model pembelajaran Contextual Teaching and Learning (CTL) mencakup tiga tahapan dalam pembelajaran daring, yaitu kegiatan pendahuluan, kegiatan inti, dan kegiatan penutup. Berikut adalah langkah-langkah model pembelajaran Contextual Teaching and Learning (CTL) yang diterapkan oleh guru pengampu mata pelajaran biologi kelas XI di SMAN 1 Grabagan.

a. Kegiatan Pendahuluan

1) Guru menyiapkan psikis dan fisik siswa sebelum dimulai proses pembelajaran.

2) Guru memberikan apersepsi kepada siswa.

3) Guru menyajikan tujuan pembelajaran dan pokok materi yang akan dipelajari.

b. Kegiatan Inti

1) Guru mengajukan permasalahan kepada siswa dan siswa menyelesaikannya.

2) Siswa mempresentasikan hasil penyelesaian permasalahan beserta alasannya.

3) Guru bersama siswa membahas cara penyelesaian masalah yang tepat dengan mengacu pada jawaban siswa, melalui tanya jawab.

4) Guru memberikan pertanyaan kepada siswa tentang hal-hal yang dirasakan siswa, materi yang belum dipahami dengan baik sebagai bagian dari refleksi.

c. Kegiatan akhir

1) Guru bersama siswa menyimpulkan terkait materi yang telah dipelajari.

2) Guru menagih tugas siswa dalam bentuk resume untuk dikumpulkan sekaligus memberi nilai.

Langkah-langkah model pembelajaran Contextual Teaching and Learning (CTL) yang diterapkan oleh guru pengampu mata pelajaran biologi kelas XI SMAN 1 Grabagan tidak dapat terlaksana secara menyeluruh. Seperti halnya pada kegiatan awal tidak terjadi langkah penjelasan tentang pembagian kelompok dan cara belajar dengan pertimbangan bahwa siswa dan guru menjadi kewalahan apabila harus membentuk kelompok terlebih dahulu karena komunikasi siswa harus terlaksana secara daring, sehingga ditakutkan akan menghambat proses pelaksanaan pembelajaran daring. Selain itu, guru khawatir terkait kurangnya antusias siswa dalam mengikuti pembelajaran daring karena fakta di lapangan hanya ketua kelompok saja yang aktif. Hal ini sebagaimana pada penelitian Hasanah, dkk (2020) menyatakan bahwa terkait kolaborasi siswa dengan guru maupun antarsiswa satu dengan yang lain saat pelaksanaan pembelajaran diperoleh data sebanyak $55,1 \%$ siswa mengalami kesulitan dalam hal berkolaborasi atau berdiskusi, selain itu ada sebanyak $37,7 \%$ yang menyatakan bahwa siswa maupun guru dalam melakukan diskusi atau berkolaborasi melalui pembelajaran daring berjalan cukup baik. Sementara itu, sisanya yakni sejumlah $7,2 \%$ siswa mengutarakan bahwa selama dilaksanakannya kegiatan berdiskusi maupun berkolaborasi dalam pembelajaran daring tidak kesulitan. Berdasarkan hal tersebut dapat diinterpretasikan bahwa siswa masih masih sangat kurang dalam hal pelaksanaan kolaborasi baik dengan guru maupun kelompok diskusi melalui media pembelajaran daring. Anugrahana (2020) juga menjelaskan bahwa salah satu yang menjadi kelemahan dengan dilaksanakannya pembelajaran daring yaitu keterlibatan siswa masih kurang maksimal. Hal ini dapat dilihat dari keikutsertaan siswa mengikuti pembelajaran secara penuh sejak awal sampai akhir. 
Langkah-langkah pada kegiatan inti yang berkaitan dengan kelompok diganti menjadi individu dengan pertimbangan bahwa sulit untuk dilaksanakan. Hal ini senada dengan penelitian yang dilakukan oleh Amar's (2020) bahwa pembelajaran secara kelompok yang dilakukan dengan jarak jauh sangat susah, berbeda dengan yang dilakukan bertemu secara langsung. Adapun kegiatan guru berkeliling untuk memandu proses penyelesaian masalah berubah menjadi memantau siswa secara daring. Selain itu, tidak ada lembar kerja yang dibagikan oleh guru karena guru menggantinya dengan tugas resume dari masing-masing siswa berdasarkan hasil yang didapatkan selama pembelajaran berlangsung yang nantinya dikumpulkan melalui foto dan dinilai oleh guru.

Pertimbangan guru menggunakan model pembelajaran Contextual Teaching and Learning (CTL) adalah kondisi siswa belajar di rumah dirasa akan lebih memungkinkan apabila pembelajaran dilakukan dengan model tersebut. Guru memperhatikan karakteristik siswa saat menggunakan model pembelajaran Contextual Teaching and Learning. Model CTL yang diterapkan guru dalam pembelajaran membuat siswa lebih mudah memahami materi karena langsung berinteraksi dengan lingkungan sekitar untuk mendapatkan pemahaman suatu materi. Hal ini sejalan dengan yang disampaikan oleh Sohimin (2014) tentang kelebihan dari model pembelajaran Contextual Teaching and Learning (CTL) yakni: (1) Mendorong siswa untuk aktif dalam berpikir secara penuh baik fisik dan mental. (2) Membentuk siswa belajar melalui proses pengalaman di kehidupan nyata bukan dengan menghafal. (3) Kelas menjadi tempat untuk menguji data hasil temuan siswa di lapangan. (4) Siswa sendiri yang menentukan materi pelajaran.

Terdapat beberapa kendala yang dialami siswa selama pelaksanaan pembelajaran daring, yaitu kendala jaringan dan kuota. Sebagaimana yang dijelaskan oleh Ita dan Esti (2020) bahwa kendala paling utama yang dirasakan siswa adalah banyaknya kuota internet yang dihabiskan serta lemahnya jaringan internet, sehingga masih perlu banyak evaluasi agar proses pembelajaran daring pada periode berikutnya semakin baik.

Implementasi model pembelajaran berbasis daring pada mata pelajaran biologi di SMAN 1 Plumpang dilakukan dengan menggunakan model pembelajaran Contextual Teaching and Learning (CTL) yang mana siswa dituntut untuk belajar mendapatkan pengetahuan dari lingkungan yang ada di sekitarnya. Secara umum tahapan proses pembelajaran biologi berbasis daring sama dengan tahapan pada proses pembelajaran tatap muka yaitu pendahuluan, kegiatan inti, dan penutup. Berikut adalah langkah-langkah model pembelajaran Contextual Teaching and Learning (CTL) yang diterapkan oleh guru pengampu mata pelajaran biologi kelas XI di SMAN 1 Plumpang.

a. Kegiatan Awal

1) Guru mempersiapkan psikis dan fisik siswa sebelum mengikuti proses pembelajaran.

2) Guru memberikan apersepsi.

3) Siswa diberikan penyampaian terkait tujuan pembelajaran dan pokok-pokok materi pembelajaran.

4) Guru memberikan penjelasan terkait pembagian kelompok dan cara belajar.

b. Kegiatan Inti 
1) Guru menyajikan permasalahan dan siswa menyelesaikan bersama kelompok masing-masing.

2) Perwakilan kelompok mempresentasikan jawaban hasil penyelesaian atas permasalahan dari guru.

3) Guru memberikan lembar kerja dan setiap kelompok diminta untuk menyelesaikannya. Guru memberikan motivasi dan mengamati secara daring.

4) Perwakilan kelompok mempresentasikan hasil kerjanya dan ditanggapi oleh kelompok lain.

c. Kegiatan akhir

1) Guru bersama siswa menarik kesimpulan terkait materi yang dipelajari.

2) Guru meminta siswa untuk mengumpulkan tugas kelompok yang telah dikerjakan.

Langkah-langkah model pembelajaran Contextual Teaching and Learning (CTL) yang diterapkan oleh guru pengampu mata pelajaran biologi kelas XI SMAN 1 Plumpang dapat berjalan cukup baik. Hanya saja kegiatan seperti guru berkeliling untuk memandu proses penyelesaian masalah berubah menjadi mengamati dan memotivasi siswa secara daring. Selain itu, pada bagian kegiatan inti hanya sampai pada langkah kelompok mempresentasikan hasil kerjanya dan ditanggapi oleh kelompok lain. Ada dua sintaks yang tidak dilaksanakan, yaitu bagian guru dan siswa membahas cara penyelesaian masalah yang tepat serta sintaks bagian guru mengadakan refleksi dengan menanyakan kepada siswa tentang hal-hal yang dirasakan siswa, materi yang belum dipahami dengan baik, kesan dan pesan selama mengikuti pelajaran.

Kegiatan pendahuluan yang dilakakukan guru biologi dalam pembelajaran biologi berbasis daring ini sudah sesuai sebagaimana yang dijelaskan oleh Tanjung (2018) dalam bukunya yang berjudul "Strategi Pembelajaran Biologi", bahwa kegiatan pendahuluan dilakukan dengan menyampaikan dan menjelaskan tujuan pendidikan dan memberikan apersepsi sebagai kegiatan penghubung antara materi sebelumnya dengan materi yang akan dipelajari dengan menyesuaikan pada kondisi strategi pembelajaran yang dilakukan.

Tahapan yang tidak dilaksanakan guru dalam kegiatan inti adalah tahapan guru dan siswa membahas cara penyelesaian masalah yang tepat serta tahapan guru memberikan refleksi. Ismail (2017) menjelaskan bahwa refleksi merupakan suatu cara yang dilakukan untuk mengetahui respon perihal yang baru saja dipelajari. Dalam hal ini guru meluangkan waktunya sejenak agar siswa melakukan refleksi berupa pernyataan secara langsung berkaitan dengan pelajaran yang didapatkan saat itu. Kemudian pada bagian penutup, tahapan yang tidak terlaksana adalah tahapan lembar tugas antarsiswa ditukar, selanjutnya guru bersama siswa melakukan pembahasan untuk penyelesaian lembar tugas dan memberi nilai (apabila waktu masih mencukupi). Pada tahap ini guru langsung meminta siswa untuk mengumpulkan tugas yang telah dikerjakan bersama kelompoknya. Pada tahap ini guru langsung meminta siswa untuk mengumpulkan tugas yang telah dikerjakan bersama kelompoknya.

Tidak terlaksananya beberapa sintaks dalam model pembelajaran pembelajaran Contextual Teaching and Learning karena beberapa pertimbangan. Pertimbangan dari guru sehingga sintaks tersebut ditiadakan yaitu masalah waktu yang tidak mencukupi. Hal ini senada dengan yang disampaikan Sohimin (2014) terkait kekurangan yang ada pada model 
pembelajaran Contextual Teaching and Learning bahwa penerapan pembelajaran kontekstual merupakan pembelajaran yang membutuhkan waktu yang lama.

Pembelajaran yang dilaksanakan pada pembelajaran biologi di SMAN 1 Soko adalah pembelajaran yang memanfaatkan jaringan internet dan bisa membuat para siswa kreatif dengan menggunakan fasilitas yang ada. Hal ini selaras dengan yang disampaikan oleh Rokhani (2020) bahwa seluruh jenjang pendidikan mulai dari sekolah dasar atau ibtidaiyah hingga perguruan tinggi (universitas) baik yang berada dibawah Kementerian Pendidikan dan Kebudayaan RI maupun yang berada dibawah Kementerian Agama RI diharuskan untuk belajar dari rumah karena pembelajaran tatap muka ditiadakan sebagai langkah untuk mencegah penularan Covid-19. Salah satu metode pembelajaran yang prosesnya dapat dilaksanakan dari rumah ialah dengan menggunakan metode pembelajaran dalam jaringan (daring). Berikut adalah langkah-langkah pelaksanaan pembelajaran oleh guru pengampu mata pelajaran biologi di SMAN 1 Soko.

a. Kegiatan Pendahuluan

Tahap pendahuluan merupakan tahap pertama yang dilakukan dalam proses pembelajaran yaitu berupa:

1) Guru mengucapkan salam untuk menyapa siswa

2) Sebagai awalan, siswa berdoa bersama.

3) Siswa menanggapi apersepsi yang diberikan oleh guru.

4) Siswa mendengarkan penyampaian guru berkaitan dengan kompetensi maupun capaian tujuan pembelajaran dan manfaatnya.

5) Siswa memberikan tanggapan secara aktif terkait materi yang akan dipelajari baik itu metode dan media, langkah pembelajaran, dan penilaian pembelajaran.

b. Kegiatan Inti

Isi pembelajaran merupakan kegiatan inti pembelajaran. Inti kegiatan pembelajaran biologi berbasis daring pada masa pandemi Covid-19 di SMAN 1 Soko adalah sebagai berikut.

1) Siswa membaca materi pembelajaran yang telah diunggah di Ms. Teams. berupa modul maupun video pembelajaran dari Youtube.

2) Siswa bertanya terkait materi yang masih kurang paham.

3) Siswa memanfaatkan modul pembelajaran dan berbagai macam sumber lain untuk menggali pengetahuan yang berkaitan dengan materi.

4) Siswa mengolah data dari hasil pengumpulan data.

5) Siswa mengerjakan tugas setelah membaca dan memahami materi di modul.

6) Guru menilai hasil kerja siswa dalam mengerjakan tugas .

7) Melalui media Ms. Team guru menanggapi jawaban dari tugas yang diberikan.

c. Penutup

1) Siswa menyimpulkan materi yang telah dipelajari .

2) Siswa menarik kesimpulan dari pembelajaran yang telah dilaksanakan.

3) Guru bersama siswa melakukan refleksi terkait kegiatan pembelajaran.

4) Siswa yang aktif mendapatkan apresiasi dari guru.

5) Siswa diberikan penguatan agar selalu semangat mengikuti pembelajaran.

6) Berdoa bersama. Salam. 
Pelaksanaan pembelajaran biologi di SMAN 1 Soko tidak dapat menerapkan model pembelajaran. Adapun pembelajaran yang terlaksana adalah dengan daring method. Alasan guru tidak menerapkan model pembelajaran daring karena guru kewalahan dalam menerapkan model pembelajaran yang tidak dilaksanakan secara tatap muka. Hal ini sebagaimana penelitian yang dilakukan oleh Taradisa (2020) bahwa adanya pembelajaran daring membuat guru menjadi kewalahan dalam menerapkan model pembelajaran yang bisa membuat siswa menjadi paham tentang materi yang disampaikan karena pembelajaran dilakukan secara daring bukan tatap muka dengan siswa secara langsung.

Penerapan model pembelajaran seperti contextual teaching and learning sangat mengutamakan terjalinnya kerja sama yang baik di antara anggota kelompok serta keberanian diri siswa dalam mengutarakan pendapat maupun bertanya. Dalam pembelajaran jarak jauh siswa kurang aktif dalam berinteraksi dengan guru maupun siswa lainnya, sehingga guru memilih untuk tidak menggunakan model pembelajaran. Hal ini sebagaimana yang disampaikan oleh Mulhamah (2016) bahwa berlangsungnya diskusi secara berkelompok dijumpai banyak siswa yang kurang aktif, sehingga kerja sama tidak terjalin dengan baik. Hal ini juga disebabkan karena kurangnya siswa dalam memperhatikan arahan maupun bimbingan guru dalam proses pembelajaran. Selain itu, juga diperkuat dengan penelitian yang dilakukan oleh Hasanah, dkk (2020) yang menyatakan bahwa terkait kolaborasi siswa dengan guru maupun antarsiswa satu dengan yang lain saat pelaksanaan pembelajaran diperoleh data sebanyak $55,1 \%$ siswa mengalami kesulitan dalam hal berkolaborasi atau berdiskusi. Selain itu, ada sebanyak $37,7 \%$ yang menyatakan bahwa siswa maupun guru dalam melakukan diskusi atau berkolaborasi melalui pembelajaran daring berjalan cukup baik. Sementara itu, sisanya yakni sejumlah $7,2 \%$ siswa mengutarakan bahwa selama dilaksanakannya kegiatan berdiskusi maupun berkolaborasi dalam pembelajaran daring tidak mengalami kesulitan.

Pembelajaran daring yang dilaksanakan oleh guru pengampu mata pelajaran biologi di SMAN 1 Soko adalah dengan memanfaatkan modul maupun video pembelajaran yang didapat dari Youtube. Sebagaimana yang disampaikan oleh Bilfaqih \& Qomarudin (2015) bahwa pembelajaran berbasis daring adalah pembelajaran yang dalam pelaksanaannya memanfaatkan teknologi seperti kelas virtual, teks online, pesan suara, email, dan video steraming online. Selama dilaksanakannya pembelajaran daring guru menggunakan aplikasi Microsoft Teams. Menurut Damayanti (2020) Microsoft Teams adalah aplikasi interaktif dalam jaringan yang dapat menjembatani guru dan siswa untuk saling berinteraksi dengan melakukan percakapan (chat) melalui fasilitas yang ada dalam Microsoft Teams. Guru dan siswa dapat mengunggah dokumen, audio, tautan laman untuk kemudian mengunduhnya sebagai informasi selama proses pembelajaran. Microsoft teams juga memberikan kemudahan dan fleksibilitas dalam berinteraksi dan berkomunikasi. Fitur utama Microsoft teams diantaranya adalah chat, panggilan audio, meeting, file, live event, dan koneksi ke perangkat lain.

Implementasi model pembelajaran berbasis daring pada mata pelajaran biologi di MAN 1 Tuban dilakukan dengan menggunakan model pembelajaran Problem Based Learning (PBL). Berikut adalah langkah-langkah model pembelajaran Problem Based Learning (PBL) yang diterapkan guru pengampu mata pelajaran biologi di MAN 1 Tuban. 
a. Kegiatan Pendahuluan

1) Guru menyampaikan tujuan pembelajaran pada pertemuan yang sedang berlangsung.

2) Guru mengaitkan materi pembelajaran yang akan dilakukan dengan pengalaman siswa pada materi sebelumnya.

b. Kegiatan Inti

1) Siswa diberi motivasi untuk terlibat dalam kegiatan pemecahan masalah.

2) Guru membantu siswa mendefinisikan dan mengorganisasikan tugas belajar yang berhubungan dengan masalah.

3) Siswa mengamati dengan saksama materi yang disampaikan oleh guru melalui gambar/video/slide presentasi sebagai langkah guru dalam membantu siswa mendapatkan informasi.

4) Siswa mengajukan pertanyaan berkaitan dengan materi.

5) Berdiskusi tentang data dari materi.

6) Siswa menyampaikan hasil diskusi tentang materi berupa kesimpulan berdasarkan hasil analisis secara lisan, tertulis, atau media lainnya.

c. Penutup

1) Guru menyimpulkan pelajaran yang sudah dibahas.

2) Guru melaksanakan penilaian pengetahuan melalui tes tertulis.

Perbedaan sintaks model pembelajaran Problem Based Learning (PBL) yang diterapkan oleh guru pengampu mata pelajaran biologi kelas XI di MAN 1 Tuban dengan sintaks dalam buku Sohimin (2014) terletak pada beberapa bagian. Pelaksanaan model pembelajaran PBL di MAN 1 Tuban terdapat kegiatan apersepsi sedangkan di sintaks dalam buku Sohimin (2014) tidak ada. Guru menyampaikan bahwa adanya apersepsi sangat penting guna memberikan rangsangan serta memusatkan perhatian siswa. Hal ini sebagaimana yang dijelaskan oleh Tanjung (2018) dalam bukunya yang berjudul "Strategi Pembelajaran Biologi", bahwa kegiatan pendahuluan dilakukan dengan menyampaikan dan menjelaskan tujuan pendidikan dan memberikan apersepsi sebagai kegiatan penghubung antara materi sebelumnya dengan materi yang akan dipelajari dengan menyesuaikan pada kondisi strategi pembelajaran yang dilakukan

Langkah guru mendorong siswa untuk mengumpulkan informasi yang sesuai, eksperimen untuk mendapatkan penjelasan dan pemecahan masalah, pengumpulan data, hipotesis dan pemecahan masalah. Langkah tersebut tidak dilasanakan karena guru cukup kesulitan dalam melaksanakannya. Hal ini selaras dengan penelitian Tyas (2017) bahwa tahap ketiga dari sintaks PBL menuntut guru untuk berperan sebagai fasilitator, membimbing, menggali, pemahaman yang lebih dalam, dan mendukung inisiatif siswa bukanlah hal yang mudah untuk dilaksanakan. Oleh karena itu, guru menggantinya dengan siswa mengamati dengan saksama materi yang disampaikan oleh guru melalui gambar/video/slide presentasi yang dapat digunakan sebagai langkah guru dalam membantu siswa mendapatkan informasi. Hal ini dilakukan agar pembelajaran lebih efektif yakni dengan langsung membagikan materi melalui media pembelajaran.

Tahapan lain yang tidak diterapkan oleh guru adalah tahap guru membantu siswa dalam merencanakan serta menyiapkan karya yang sesuai seperti laporan dan membantu 
mereka berbagai tugas dengan temannya. Guru tidak menuntut siswa untuk membuat karya dan guru mengajak siswa untuk berdiskusi secara aktif terkait data yang telah dikumpulkan setelah mengamati materi yang disampaikan oleh guru sebelumnya. Guru juga tidak membentuk kelompok-kelompok kecil karena yang sering terjadi di lapangan adalah siswa berkemampuan tinggi yang seharusnya membantu teman yang berkemampuan rendah justru cenderung egois. Begitu pula dengan yang berkemampuan rendah tidak peduli dengan dirinya sendiri. Hal ini sebagaimana penelitian yang dilakukan oleh Tyas (2017) bahwa penerapan PBL di lapangan kadang juga tidak sesuai harapan karena kelompok siswa berkemampuan tinggi yang seharusnya mampu membantu temannya yang kurang seringkali tidak berjalan seharusnya. Siswa dengan kelompok berkemampuan tinggi kadang memiliki keegoisan yang tinggi dan kadang siswa yang berkemampuan rendah juga tidak peduli dengan diri mereka sendiri sehingga tidak ada usaha untuk mengejar ketertinggalan dari temannya. Alasan lain tidak dibentuknya kelompok kecil karena untuk menghindari siswa berkerumun disaat pandemi Covid-19.

Pertimbangan guru menggunakan model pembelajaran PBL karena dengan keadaan siswa yang belajar dari rumah siswa dapat menggunakan masalah dalam dunia nyata untuk membentuk pengetahuan siswa serta melatih kemandirian belajar. Hal ini sesuai dengan pengertian PBL menurut Arends (2008) bahwa PBL merupakan suatu pendekatan pembelajaran yang berfokus pada siswa dengan menggunakan masalah pada dunia nyata yang bertujuan untuk menyusun pengetahuan siswa, melatih kemandirian, dan rasa percaya diri serta mengembangkan keterampilan berpikir siswa dalam pemecahan masalah. Hal ini senada dengan penelitian yang dilakukan oleh Amar's (2020) bahwa belajar kelompok dengan jarak jauh sangat susah dan tidak semudah berdiskusi secara langsung. Selain itu, banyak kelebihan dengan diterapkannya model pembelajaran PBL sebagaimana yang dipaparkan oleh Sohimin (2014) yakni sebagai berikut.

a. Siswa dituntut untuk memiliki kemampuan dalam memecahkan masalah dalam situasi nyata.

b. Siswa mempunyai kemampuan dalam memecahkan masalah dengan kondisi yang nyata.

c. Melalui aktivitas belajar siswa dituntut untuk mampu membangun pengetahuannya sendiri.

d. Pembelajaran berfokus pada masalah dengan hal ini dapat mengurangi beban pada siswa.

e. Melalui kerja kelompok menyebabkan terjadinya aktivitas siswa secara ilmiah.

f. Siswa terbiasa menggunakan sumber-sumber pengetahuan, baik dari buku, internet, wawancara maupun observasi.

g. Siswa juga memiliki kemampuan untuk menilai kemajuan belajarnya sendiri.

h. Siswa harus mampu untuk komunikasi secara ilmiah dalam kegiatan diskusi atau presentasi.

Pembelajaran pada masa pandemi sekarang ini menjadikan seluruh pembelajaran yang awalnya tatap muka beralih menjadi sistem daring karena seluruh kegiatan pembelajaran dilakukan di rumah masing-masing. MAN 2 Tuban merupakan salah satu sekolah yang menerapkan sistem pembelajaran daring tersebut. Implementasi model 
pembelajaran berbasis daring pada mata pelajaran biologi di MAN 2 Tuban dilakukan dengan menggunakan model pembelajaran Contextual Teaching and Learning (CTL).

Model pembelajaran Contextual Teaching and Learning (CTL) dipilih oleh guru dengan memperhatikan situasi dan kondisi siswa yang pembelajarannya dilaksanakan secara daring di rumah masing-masing. Hal ini sesuai dengan pendapat Hidayat (2011) yang menyampaikan bahwa model pembelajaran yang paling baik adalah yang paling sesuai dengan karakteristik siswa, tujuan, materi ajar, alat/media, waktu yang tersedia, situasi dan kondisi. Selain itu juga mengacu pada surat edaran Kementerian Pendidikan dan Kebudayaan (Kemendikbud) No. 4 tahun 2020 tentang pelaksanaan kebijakan pendidikan dalam masa darurat penyebaran Corona Virus Disesase (Covid-19) terkait proses belajar menyatakan bahwa belajar dari rumah melalui pembelajaran daring/jarak jauh dilaksankan untuk memberikan pembelajaran yang bermakna bagi siswa. Berikut adalah langkahlangkah model pembelajaran Contextual Teaching and Learning (CTL) yang diterapkan oleh guru pengampu mata pelajaran biologi kelas XI di MAN 2 Tuban.

a. Kegiatan Pendahuluan

1) Guru terlebih dahulu menyiapkan siswa secara psikis dengan selalu memberikan pre tes pada setiap pertemuan.

2) Guru memberikan apersepsi sebagai penggalian pengetahuan awal siswa terhadap materi yang akan diajarkan.

3) Guru menyampaikan tujuan pembelajaran dan pokok-pokok materi yang akan dipelajari. Tujuan pembelajaran disampaikan seluruhnya pada pertemuan pertama awal semester.

4) Penjelasan tentang cara belajar.

b. Kegiatan Inti

1) Siswa bekerja secara individu menyelesaikan permasalahan yang diajukan guru.

2) Siswa secara individu mempresentasikan hasil penyelesaian dan alasan atas jawaban permasalahan yang diajukan guru dan siswa yang lain menanggapi.

3) Guru dan siswa membahas cara penyelesaian masalah yang tepat dengan mengacu pada jawaban siswa, melalui tanya jawab.

4) Guru mengadakan refleksi dengan menanyakan kepada siswa tentang hal-hal yang dirasakan siswa, materi yang belum dipahami dengan baik, kesan dan pesan selama mengikuti pelajaran.

c. Kegiatan akhir

1) Guru bersama siswa menarik kesimpulan terkait materi yang telah dipelajari.

2) Guru bersama siswa membahas penyelesaian tugas dalam bentuk resume sekaligus memberi nilai.

Langkah-langkah model pembelajaran Contextual Teaching and Learning (CTL) yang diterapkan oleh guru pengampu mata pelajaran biologi kelas XI MAN 2 Tuban tidak dapat terlaksana secara menyeluruh. Seperti halnya pada kegiatan awal tidak terjadi langkah penjelasan tentang pembagian kelompok dan cara belajar dengan pertimbangan bahwa siswa dan guru menjadi kewalahan apabila harus membentuk kelompok terlebih dahulu karena komunikasi siswa harus terlaksana secara daring yang mana ditakutkan akan menghambat proses pelaksanaan pembelajaran daring. Selain itu, guru khawatir terkait 
antusias siswa dalam mengikuti pembelajaran daring karena fakta di lapangan ketika dibentuk kelompok hanya ketua kelompok saja yang aktif. Hal ini sebagaimana pada penelitian yang dilakukan oleh Hasanah, dkk (2020) bahwa terkait kolaborasi siswa dengan guru maupun antarsiswa satu dengan yang lain saat pelaksanaan pembelajaran diperoleh data sebanyak $55,1 \%$ siswa mengalami kesulitan dalam hal berkolaborasi atau berdiskusi, selain itu ada sebanyak 37,7\% yang menyatakan bahwa siswa maupun guru dalam melakukan diskusi atau berkolaborasi melalui pembelajaran daring berjalan cukup baik. Sementara itu, sisanya yakni sejumlah $7,2 \%$ siswa mengutarakan bahwa selama dilaksanakannya kegiatan berdiskusi maupun berkolaborasi dalam pembelajaran daring tidak mengalami kesulitan. Anugrahana (2020) juga menjelaskan bahwa salah satu yang menjadi kelemahan dengan dilaksanakannya pembelajaran daring yaitu keterlibatan siswa masih kurang maksimal. Hal ini dapat dilihat dari keikutsertaan siswa mengikuti pembelajaran secara penuh sejak awal sampai akhir.

Tidak dilaksanakannya pembagian kelompok justru memberikan sisi positif bagi siswa yakni menumbuhkan kemandirian belajar. Menurut Herliandry, dkk (2020) bahwa pembelajaran daring meningkatkan keterlibatan siswa yang lebih besar untuk meningkatkan perilaku belajar observasional. Perilaku tersebut dapat dilakukan dengan membaca, memaknai postingan diskusi, dan mendiskusikan video atau konten pembelajaran. Kemudian pada kegiatan inti semua langkah yang berkaitan dengan kelompok diganti menjadi individu. Hal ini senada dengan penelitian yang dilakukan oleh Amar's (2020) yang mendapati bahwa siswa tetap melakukan dan mendapatkan tugas berkelompok dari guru mereka. Siswa menggunakan aplikasi Whatsapp dan Line dalam melaksanakan tugas dari guru. Menurut siswa pengerjaan tugas kelompok dengan bantuan aplikasi tersebut sudah sangat membantu. Namun, belajar kelompok dengan jarak jauh sangat susah dan tidak semudah berdiskusi secara langsung. Adapun untuk kegiatan guru berkeliling untuk memandu proses penyelesaian masalah berubah menjadi memantau siswa secara daring. Selain itu, tidak ada lembar kerja yang dibagikan oleh guru karena guru menggantinya dengan tugas resume dari masing-masing siswa berdasarkan hasil yang didapatkan selama pembelajaran berlangsung yang nantinya dikumpulkan melalui foto dan dinilai oleh guru.

Pertimbangan guru menggunakan model pembelajaran Contextual Teaching and Learning adalah guru berpikir bahwa biologi itu pembelajaran berbasis logika yang mana bisa dirasakan dan bisa dilihat, seperti halnya penyakit atau gangguan pada sistem pernapasan. Selain itu, berdasarkan pengalaman guru dalam mengajar, siswa sangat antusias dengan kelainan yang terjadi pada sistem dan gangguannya. Sehingga model pembelajaran Contextual Teaching and Learning (CTL) ini sangat tepat digunakan. Hal ini sejalan dengan yang disampaikan oleh Sohimin (2014) tentang kelebihan dari model pembelajaran Contextual Teaching and Learning (CTL) yakni: (1)Pembelajaran kontekstual dapat menekankan aktivitas berpikir siswa secara penuh, baik fisik maupun mental. (2) Pembelajaran kontekstual dapat menjadikan siswa belajar bukan dengan menghafal, melainkan proses berpengalaman di kehidupan nyata. (3) Kelas dalam kontekstual bukan sebagai tempat untuk memperoleh informasi, melainkan sebagai tempat untuk menguji data hasil temuan siswa di lapangan dan (4) Materi pelajaran ditentukan oleh siswa sendiri, bukan hasil pemberian dari orang lain. 


\section{SIMPULAN}

Berdasarkan pelaksanaan penelitian yang dilakukan di SMA/MA Negeri di kabupaten Tuban, penulis dapat menyimpulkan bahwa implementasi model pembelajaran berbasis daring pada mata pelajaran biologi kelas XI SMA/MA Negeri di Kabupaten Tuban adalah (1) Model pembelajaran berbasis daring yang digunakan oleh SMAN 1 Grabagan, SMAN 1 Plumpang, dan MAN 2 Tuban adalah Contextual Teaching and Learning (CTL). MAN 1 Tuban menggunakan model pembelajaran Problem Based Learning (PBL), sedangkan untuk SMAN 1 Soko menerapkan pembelajaran daring method. (2) Implementasi model pembelajaran berbasis daring di SMAN 1 Grabagan sebagian besar sudah sesuai dengan sintaks pembelajaran CTL, tetapi ada tahapan yang tidak disertakan karena pertimbangan tertentu yaitu tahapan pembagian kelompok yang pelaksanaannya berubah menjadi individu. Implementasi model pembelajaran berbasis daring di SMAN 1 Plumpang terdapat beberapa sintaks pembelajaran CTL yang tidak diterapkan karena adanya pertimbangan tertentu. Sintaks yang tidak dilaksanakan adalah tahapan guru dan siswa membahas cara penyelesaian masalah yang tepat serta guru mengadakan refleksi. MAN 2 Tuban dalam implementasi model pembelajaran berbasis daring juga tidak menerapkan beberapa sintaks pembelajaran CTL, yaitu tahapan pembagian kelompok dan pemberian lembar kerja siswa diganti dengan tugas individu dan resume materi karena adanya pertimbangan tertentu dari guru. Sementara itu, implementasi model pembelajaran berbasis daring di MAN 1 Tuban sebagian besar sudah sesuai dengan sintaks pembelajaran PBL, meskipun begitu terdapat beberapa sintaks yang tidak dilaksanakan, yaitu tahapan siswa membuat karya dan guru membentuk kelompok-kelompok kecil. Terkait tidak dilaksanakannya beberapa sintaks pembelajaran PBL karena ada pertimbangan tertentu. Implementasi pembelajaran berbasis daring di SMAN 1 Soko yaitu dengan daring method. Langkah-langkah daring method meliputi kegiatan pendahuluan, kegiatan inti, dan penutup. Aplikasi yang digunakan adalah Microsoft Team.

\section{UCAPAN TERIMA KASIH}

Penulis menyampaikan ucapan terima kasih kepada semua pihak yang terlibat dalam penulisan skripsi ini. Khususnya penulis ucapkan terimakasih kepada : Dr. Nur Khoiri, M. Ag. selaku dosen pembimbing I dan Ndzani Latifatur Rofi'ah, M.Pd. selaku dosen pembimbing II yang sudah memberikan waktu dan pemikirannya untuk membimbing penulis dalam menyelesaikan skripsi ini dan kepada kepala sekolah dan guru SMA/MA negeri kelas XI di Kabupaten Tuban yang sudah memberikan izin kepada penulis untuk melakukan penelitian dan memberikan informasi, arahan serta bimbingan dalam penelitian.

\section{RUJUKAN}

Amar's, I. P. I. 2020. Analisis Kendala dan Alternatif Pembelajaran Biologi pada Masa Pandemi Covid-19 di SMA Swasta Yapim Taruna Dolok Masihul. Skripsi. Medan: UIN Sumatra Utara.

Anderson, T. 2004. Toward A Theory Of Online Learning. In T. Anderson \& F. Elloumi (Eds.), Theory And Practice Of Online Learning (pp. 33-59).

Anhusadar, L. 2020. Persepsi Mahasiswa PIAUD Terhadap Kuliah Online Di Masa Pandemi Covid19. KINDERGARTEN: Journalof Islamic Early Childhood Education. 3(1): 44-58.

Anugrahana, Andri. 2020. Hambatan, Solusi dan Harapan: Pembelajaran Daring Selama Masa Pandemi Covid-19 Oleh Guru Sekolah Dasar. Jurnal Universitas Sanata Dharma. 8(3): 282-289. 
Arends, R. 2008. Learning to Teach. Jakarta: Pustaka Belajar.

Bilfaqih, Y., \& Qomarudin, M. N. 2015. Esensi Pengembangan Pembelajaran Daring. Yogyakarta: Deepublish.

Hasanah, A., Lestari, A. S., Rahman, A. Y., \& Daniel, Y. I. 2020. Analisis Aktivitas Belajar Daring Mahasiswa Pada Pandemi Covid-19 [Workshop]. Kti Masa Wfh Lp2m. Diunduh di Http://Digilib.Uinsgd.Ac.Id/30565/ tanggal 15 Juni 2021.

Herliandry, L. D., Nurhasanah, N., Suban, M. E., \& Kuswanto, H. 2020. Pembelajaran pada Masa Pandemi Covid-19. JTP-Jurnal Teknologi Pendidikan, 22(1): 65-70.

Hidayat, K. 2011. Penggunaan Model Pembelajaran Reciprocal Untuk Meningkatkan Keterampilan Pasing Bawah Permainan Bola Voli Mini Pada Siswa Kelas V Sekolah Dasar Negeri Sinom Widodo 02 Kabupaten Pati Tahun Pelajaran 2010-2011. Skripsi. Semarang: Unnes.

Hui, D. S., I Azhar, E., Madani, T. A., Ntoumi, F., Kock, R., Dar, O., ... Petersen, E. 2020. The Continuing 2019-nCoV Epidemic Threat of Novel Coronaviruses to Global health - The Latest 2019 Novel Coronavirus Outbreak in Wuhan, China. International Journal of Infectious Diseases. 91: 264-266.

Ismail. 2017. Penerapan Model Pembelajaran Contextual Teaching and Learning (CTL) Untuk Meningkatkan Hasil Belajar Siswa Kelas VIII pada Materi Gerak Lurus Di SMPN 2 Banda Aceh. Skripsi. Banda Aceh: UIN Ar-Raniry.

Lestariyanti, E. 2020. Mini Review Pembelajaran Daring Selama Pandemi Covid 19: Keuntungan Dan Tantangan. Jurnal Perkasa Paedagogia. 3(1): 89-96.

Mantra, I. B. N., Widiastuti, I. A. M. S., \& Pramawati, A. A. I. Y. 2020. Peningkatan Kompetensi Mengajar Secara Online Bagi Para Guru Selama Pandemi Virus Corona. Jurnal Abdi Dharma Masyarakat (JADMA), 1(1): 12-20.

Menteri Pendidikan dan Kebudayaan Republik Indonesia. (2020). Surat Edaran Nomor 15 Tahun 2020 Tentang Pedoman Penyelenggaraan Belajar Dari Rumah Dalam Masa Darurat Penyebaran Corona Virus Disease (Covid-19).

Mulhamah \& Putrawangsa, S. 2016. Penerapan Pembelajaran Kontekstual dalam meningkatkan Kemampuan Pemecahan Masalah Matematika. Jurnal Pendidikan Matematika. 10 (1).

Muthuprasad, T., Aiswarya, S., Aditya, K.S. \& Jha, Grish K. 2020. Students' Perception And Preference For Online Education In India During COVID-19 Pandemic. Jurnal Elsevier Social Sciences \& Humanities Open. 3: 1-11.

Rokhani, C. T. S. 2020. Pengaruh Work From Home (WFH) Terhadap Kinerja Guru SD Negeri Dangkek 01 Pati Selama Masa Pandemi Covid-19. Journal Of Education, Psychology And Counseling. 2(1): 2716-4446.

Shohimin, Aris. 2014. Model Pembelajaran Inovatif dalam Kurikulum 2013. Yogyakarta: Ar Ruzz Media.

Sugiyono. 2016. Metode Penelitian Pendidikan: Pendekatan Kuantitatif, Kualitatif, dan R\&D. Bandung: CV. Alfabeta.

Sukanto, D. 2020. Pembelajaran Jarak Jauh Dengan Media E-Learning Sebagai Solusi pada Masa Pandemi Coronavirus Disease 2019 (Covid-19). Jurnal Syntax Idea. 2(11): 834-850.

Tanjung, Indayana Febriani. 2018. Strategi Pembelajaran Biologi. Medan: CV Widya Puspita.

Taradisa, Nindia., Jarmita, Nida., \& Emalfida. 2020. Kendala Yang Dihadapi Guru Mengajar Daring pada Masa Pandemi Covid-19 Di MIN 5 Banda Aceh. Skripsi. Banda Aceh: UIN Ar-Raniry.

Tyas, R. 2017. Kesulitan Penerapan Problem Based Learning dalam Pembelajaran Matematika. Jurnal Tecnoscienza. 2(1).

Virawardina, U., Asnur, L., Lubis, A. L., \& Hendriyani, Y. 2020. Reviewing Online Learning Facing The Covid-19 Outbreak. Talent Development \& Exellence. 12(3): 385-392. 